\title{
A Colour Perception Detection Model Based on The Spectral Characterictics
}

\author{
Irwanto ${ }^{1, a}$ \\ ${ }^{1}$ Department of Electrical Engineering Vocational Education, UNTIRTA, Indonesia. \\ Jl. Raya Jakarta KM 4 Pakupatan Serang-Banten \\ airwanto.ir@untirta.ac.id
}

\begin{abstract}
Abstrak.
Kebutuhan informasi untuk persepsi warna seseorang diperlukan di bidang kedokteran, teknik, astronomi, biomedis dan sebagainya. Permintaan untuk penilaian persepsi warna yang akurat harus dipenuhi oleh alat pendeteksi persepsi yang digunakan. Tes Ishihara, sebagai alat pendeteksi persepsi yang masih digunakan sampai sekarang, memiliki akurasi yang kurang memadai. Penelitian ini bertujuan untuk membuat sistem yang dapat mendeteksi pergeseran persepsi warna seseorang, relatif terhadap persepsi warna rata-rata sejumlah responden. Dengan memplot poin persepsi responden, dalam sistem koordinat CIE (Commission International de I'Eclairage) XYZ dapat dihitung jarak rata-rata euclidean, ED, relatif terhadap titik referensi dan distribusi kelompok persepsi $\mathrm{x}$ dan y di sekitar titik referensi. Baik ukuran, jarak euclidean dan distribusi digunakan sebagai indikator persepsi warna rata-rata sehingga penilaian persepsi warna seseorang diberikan berdasarkan hasil perbandingan antara titik persepsi warna dan indikator persepsi warna. Alat yang digunakan untuk melakukan tes adalah perangkat lunak Delphi versi 7.0. bahan penelitian yang digunakan adalah format gambar warna RGB (Merah, Hijau, Biru). Hasil studi persepsi warna seseorang dibagi menjadi tiga tingkatan, yaitu: (1) penilaian "normal" jika persepsi euclidean (ED) lebih kecil dari rata-rata euclidean (ED) (2) penilaian "agak normal" jika distribusi dari $\mathrm{x}$ dan y lebih kecil daripada warna persepsi dan distribusi $\mathrm{x}$ dan y (3) penilaiannya "abnormal" jika warna persepsi lebih besar dari distribusi maksimum x dan y. Penilaian titik persepsi baru yang ada di tingkat satu digunakan untuk memperbarui indikator persepsi yang berlaku. Kendala kondisi up-dating mempengaruhi kualitas persepsi rata-rata ambang batas secara khusus dan kualitas hasil sistem deteksi persepsi secara umum.
\end{abstract}

Kata kunci. Warna, deteksi, persepsi, spektral

\begin{abstract}
.
Information needs for one's color perception are needed in the fields of medicine, engineering, astronomy, biomedicine and so on. The demand for accurate assessment of color perception must be met by the perception detection tool used. Ishihara's test, as a perception detection tool that is still used today has insufficient accuracy. This research aims to create a system that can detect a shift in one's color perception, relative to the average color perception of a number of respondents. Through plotting the respondents' perception points, in the CIE coordinate system (Commission International de I'Eclairage) XYZ can be calculated the average euclidean distance, ED, relative to the reference point and the distribution of $x$ and $y$ groups of perception points around the point of reference. Both size, euclidean distance and distribution are used as
\end{abstract}


indicators of average color perception so that an assessment of one's color perception is given based on the results of comparison between color perception points and color perception indicators. The tool used to do the test is Delphi version 7.0 software. the research material used is the RGB (Red, Green, Blue) color image format. The results of a person's color perception study are divided into three levels, namely: (1) "normal" assessment if euclidean (ED) perceptions are smaller than the euclidean (ED) average (2) the "somewhat normal" assessment if the distribution of $x$ and $y$ is smaller rather than the color of perception and the distribution of $x$ and $y$ (3) the assessment is "abnormal" if the color of perception is greater than the max distribution of $x$ and $y$. A new perception point assessment that is in level one is used to up-date prevailing perception indicators. Up-dating condition constraints affect the quality of the threshold average perception specifically and the quality of the results of the perception detection system in general.

Keywords. Colour, detection, perception, spectral

\section{Introduction}

The rapid development of digital and analog electronic technology in the past twenty years has spurred the development of hardware, especially computers, to create increasingly sophisticated personal computers (personal computers). Along with the development of hardware technology, software technology is also experiencing very rapid development, thus spurring the application of personal computers. The advancement of computer technology and data recording can be digitally processed using a computer, after the original image data is converted from optical or analog to electrical or digital. By using a computer, processing can be done much faster and it is possible to use it in a wide variety of applications. Applied digital image processing is growing rapidly along with the development of computer technology, especially in the ability to process data with high speed and capacity data storage is getting bigger. The history of the development of image processing systems is not only driven by the need for remote sensing but also in other applications such as the fields of astronomy, medicine, biomedicine, forestry, industry and so on.

The color receiver devices are sensitive to blue, green and red light together, together these three impulses produce a single color in the detection of color perception based on spectral so that humans depend on the amount of reflection of certain objects in the blue, green spectrum and red. Changes in the amount of blue, green and red light coming from objects change the color received from that object. Humans accept all colors by combining the three numbers relatively [1]. For ease of color interpretation by the human eye, this study focused on spectral based color perception detection. The color sharing criteria used are in the form of certain similarities in a pixel with surrounding pixels [2].

Every pixel on the existing display hardware has been able to display 24-bit color resolution with 8 bits of red, green and blue, one 24-bit pixel and display 1 of $224 \approx 16.78$ million colors. Images with a spatial resolution of 512x512 and 24-bit color resolution require 786,432 bytes of storage location. The need is 4 times greater at the spatial resolution of $1024 \times 1024$. Based on the above, the author intends to create a spectral based color perception detection system [3]. Color is a meeting of light in the visible spectrum region that occurs in the retina, with wavelengths between 400 to 700 
$\mathrm{nm}$ [4]. Human perception of light is generally described in brightness (color), color (hue) and color saturation (saturation).

The problem in this study is how to make the system to detect color perceptions based on spectral, this system can know quantitatively the color assessment of one's perception and can know the difference between the average perception assessment based on the amount of previous assessment data. Usually this technique produces several forms of imagery which are then processed and interpreted to produce data that is useful for applications in agriculture, archeology, forestry, geography, land planning and other fields [5]. In general, image processing can be classified into 6 parts, namely image modeling and implementation, image enhancement, image restoration, image analysis, image reconstruction and compression of image data [6]. The image classification process is a sub-section of image analysis. In the subtractive color model, the formation of a color occurs due to absorption (removal) of several components of white light. Certain color components that are omitted in this subtractive color model will not contribute to the formation of a color. If all components of the color are white, what appears is black, on the contrary if reflected all appear white [7].

Image (image) is an image in a two-dimensional (2-D) field, so each of these images is a spatial dimension or 2-D space that contains color information and does not depend on time. Judging from a mathematical angle, the image is a continuous function of the intensity of light in a two-dimensional field. The light source illuminates the object, the object reflects back all or part of the beam of light, then is captured by optical devices, such as the eyes on humans, scanners (scanners) and so on, so that the image of objects called images can be recorded.

The image is composed of a number of pixels that make up the matrix. The pixel is the smallest component of the image containing information. Each pixel of a color image contains three basic color components, namely the red component (red), green components (green) and blue components (blue) which are often referred to as RGB components. For example red will be represented by a point $(255,0,0)$, the range of values for each axis ranges from 0 to 255 [8]. Measuring two pixels or two image components is required in many applications, both for the final destination and for intermediate purposes. Common methods used to measure the distance of two points on an image are:

\section{Euclidean Distance}

To calculate the euclidean distance distance of each respondent with $d$ average or normal reference, then distance measurement by euclidean distance is more widely used because it produces fraction values. The reference point $(x 0, y 0)$ and point $d 1, d 2, d 3, d 4, d 5, \ldots \ldots \ldots$ dn is the point of one's perception. $d 1=(x 1, y 1), d 2=(x 2, y 2), d 3=(x 3, y 3), d 4=(x 4, y 4), d 5=(x 5, y 5), \ldots \ldots \ldots d n=$ $(x n, y n)$.

\section{Distribution Theory}

Distribution is the two most commonly used measures of the distribution of a data set [9]. The size is directly related, one size can be found directly if other sizes are known. The distribution is the square of the standard deviation and vice versa. The standard deviation is the square root of the distribution. Distribution analysis is a statistical analysis technique developed and first introduced by Sir R. A Fisher [10]. 


\section{Research Methods}

The research material used is data in the RGB color image format, so that there are two forms of colors used, namely the reference color and the color of perception. The tools used in this study are a set of computers, printers, Windows XP operating systems, Delphi 7.0 and Microsoft point programming software, standards used in research and the creation of spectral based color perception detection programs. The research process about color perception is as follows: (1) The process of assessing color perception begins with determining the color of the reference that is done by generating a reference color by selecting RGB colors $=\{$ random (255), random (255), random (255)\}. The generator chooses to ensure that the colors obtained are unique. (2) The process of evaluating perceptions is basically comparing between perception colors and reference colors. The color of perception is obtained through the control settings that are in the user interface of the user interface. For RGB channels, three controls are provided which consist of RGB intensity control. (3) After the respondent considers the color of perception "equal to" the color of the reference, then the save button is pressed to save the color of perception to the database so that color perception data can be saved to the database. (4) The next respondent performs a sequence of activities 1-3, up to a number of $\mathrm{N}$ respondents, an analysis of stored perception data can be carried out which includes euclidean distance and distribution. (5) In the euclidean distance and distribution values for $\mathrm{N}$ respondents, it can be used to assess respondents' perceptions to $\mathrm{N}+1$. (6) It is said that the perception of respondent $\mathrm{X}$ has shifted, if the distance of the perception and reference points > and the euclidean distance. Then the perception point is outside the distribution. Whereas the perception and reference point distance < then the perception of respondent $\mathrm{X}$ was not shifted (the perception of the respondent was normal) so that the perception point was in the distribution.

\section{Results and Discussion}

The results of respondents 'perception data in the CIE 1931 system, below shows the point of reference color which is surrounded by respondents' perception data. The respondent's perception data contained in the automation curve is the earliest data in spectral based color perception data collection. The choice of color as the reference color is in a certain area on the CIE curve so that it can represent different color perceptions in the CIE curve. Note Figure 1 below shows the results of respondents' perception data in the CIE 1931 system [11].

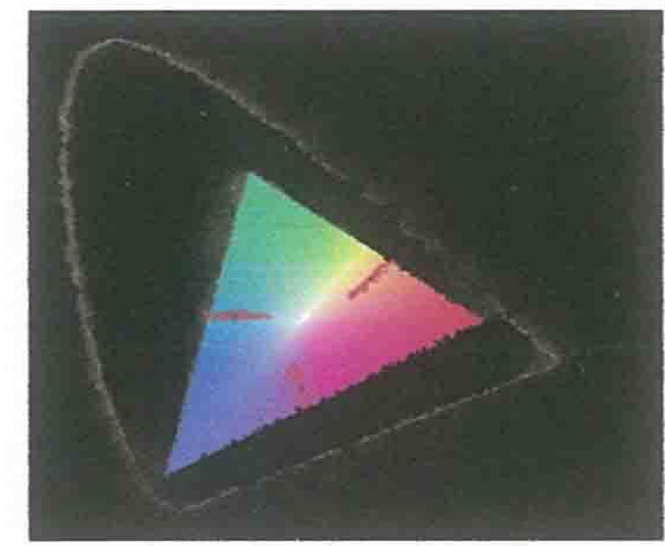

Figure 1. plotting perceptual data and references in XYZ (CIE 1931)

Respondent data stored in the data base is the color of RGB perception with quantitative quantities R, G and B. Quantitative quantities, for example, the value $R=248, G=169$ and $B=0$, 
are the RGB values stored in in the data base. From the results of the above perception data can be analyzed by looking for euclidean distance and distribution. To find out the analysis in this study, the parameters used are euclidean and distribution. It is expected that in the analysis the euclidean distance and distribution output.

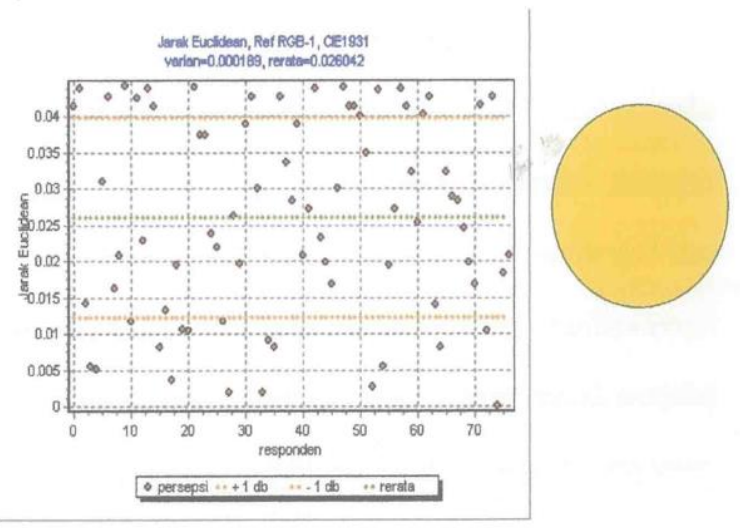

Figure 2. RGB 1 euclidean reference distance (CIE 1931)

Figure 1 is an analysis of the calculation of the euclidean distance in tristimulus-x and tristimulus-y in the XYZ system (CIE 1931). In this case to obtain variant and mean values, it is calculated euclidean distance analysis from both tritimulus- $x$ and tritimulus-y then use the euclidean distance equation.

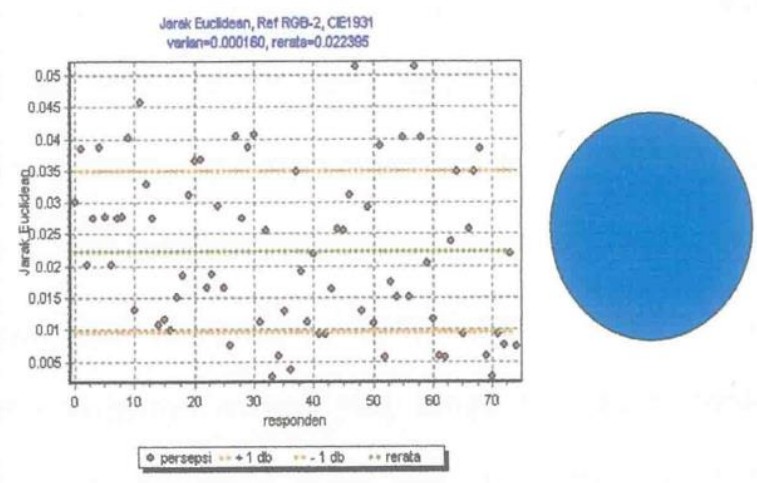

Figure 3. RGB 2 euclidean reference distance (CIE 1931)

Figure 3 above can be seen that all data entered into the value of $+1 \mathrm{db}$ and $-1 \mathrm{db}$, the results of the perception are normal. The meaning of the picture above is to find out the sensitivity threshold of the second reference color of CIE in 1931. In this second reference some perceptual data away from these two values, so it can be said that the data said that the respondent experienced a color shift in the reference second. 


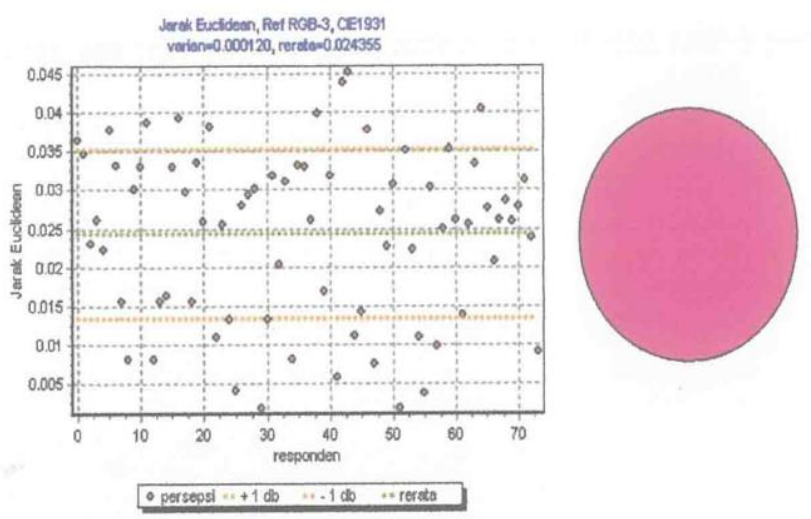

Figure 4. Euclidean RGB 3 reference distance (CIE 1931)

Figure 4 above shows that the value of the variant obtained is quite small compared to the reference colors 1 and 2. The Euclidean distance obtained by both tristimulus-x and tristimulus-y can provide information about the threshold of a color sensitivity, especially the third reference.

Parameters to determine whether a person is color blind or not, the analysis parameters are needed, namely euclidean distance and distribution. Distribution analysis consists of two, namely the $\mathrm{x}$ direction distribution and the y-direction distribution on the CIE system in 1931. Figure 4 (a) below shows the results of the $\mathrm{x}$-direction distribution associated with the perception data on tristimulus-x. in this picture shows the variance value and mean value with meaning to know the reference color sensitivity threshold 1. The y-direction distribution is obtained from the perception data on tristimulus-y so that it can produce Figure 5 (b) as below. The variance and mean values were obtained from y-distribution with the aim of finding the color sensitivity threshold [12].
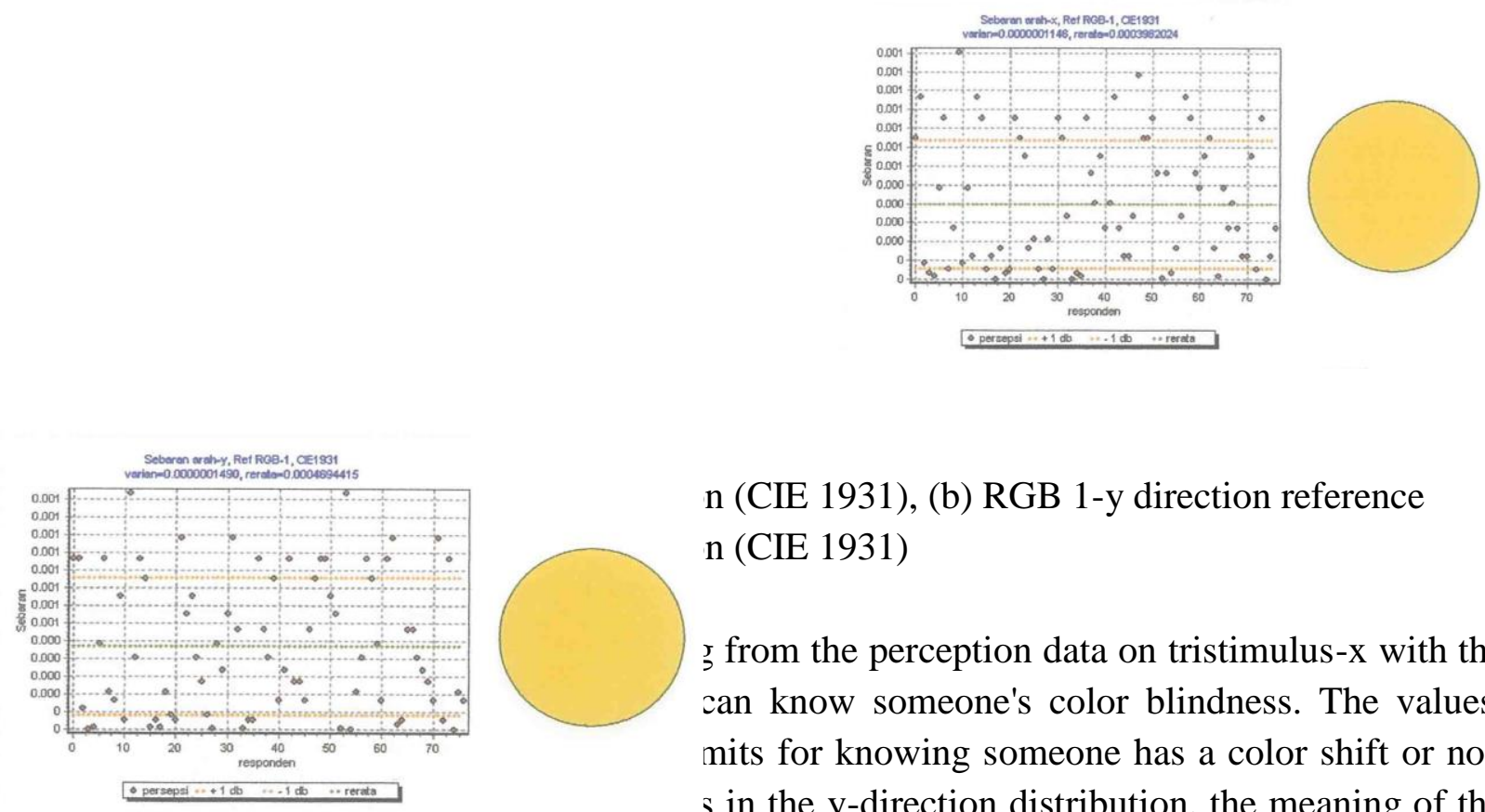

n (CIE 1931), (b) RGB 1-y direction reference n (CIE 1931)

s from the perception data on tristimulus- $x$ with the can know someone's color blindness. The values mits for knowing someone has a color shift or not. $s$ in the y-direction distribution. the meaning of the variant value is to find the sensitivity value of a color from each reference color. 

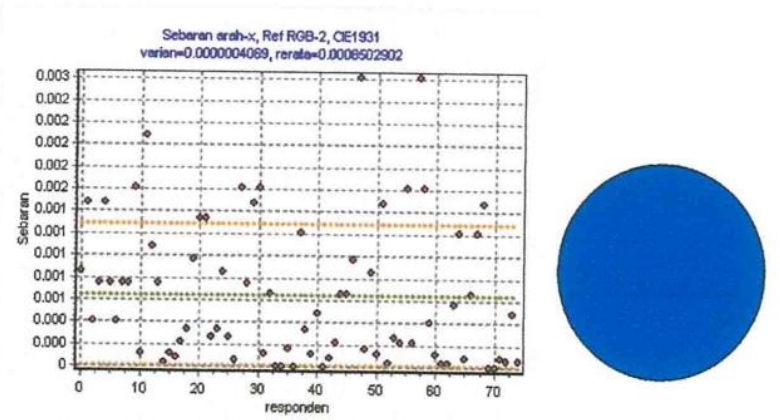

persepsi $\cdots+1$ do $\quad \cdots 1$ 1

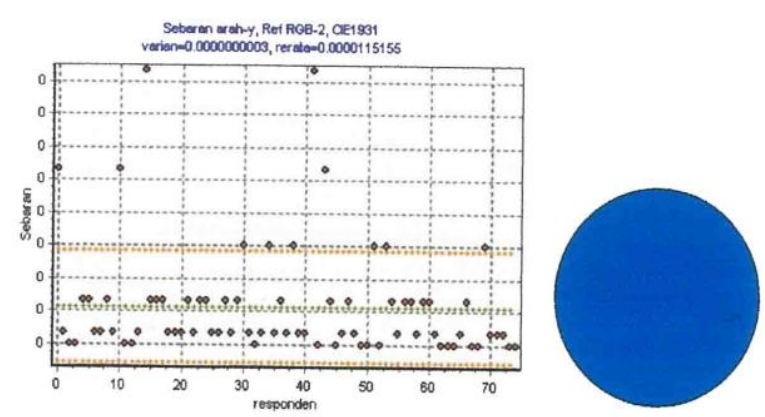

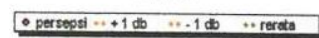

Figure 6. (a) RGB 2-direction reference x 2 distribution (CIE 1931), (b) RGB 2-y reference direction distribution (CIE 1931)

The distribution values in the x-direction shown in Figure 6 below are related to the initial data on the automation curve. So that the perception data is sought for the $\mathrm{x}$-direction distribution shown in Figure 7 (a). Figure 6 (b) is the result of the y-direction distribution for the third reference color, where all the results of the perception can be known through the value of $+1 \mathrm{db}$ and the value of -1 $\mathrm{db}$.

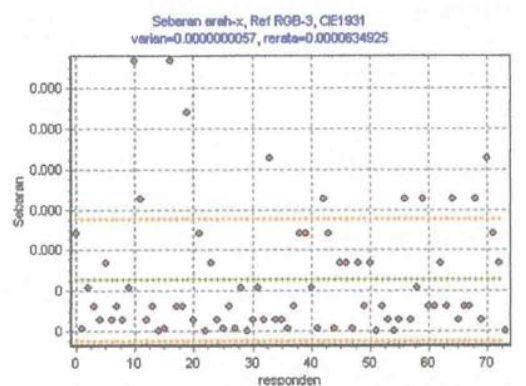

0 persepsi $\cdots+1$ 10
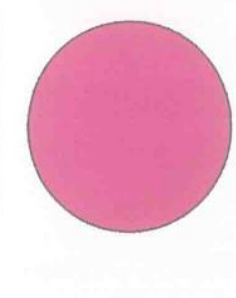

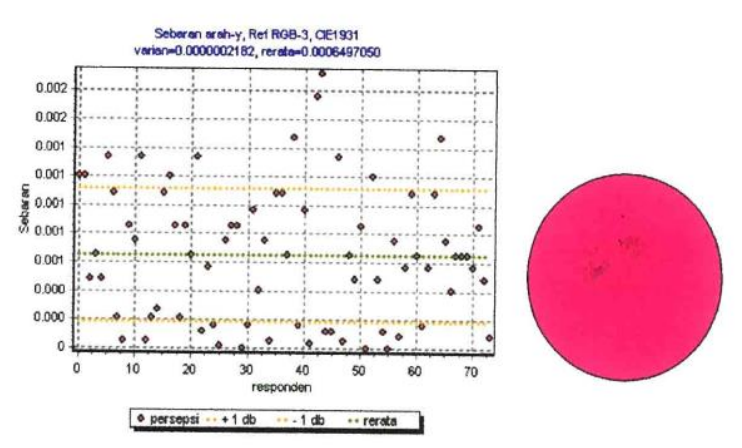

Figure 7. (a) x-direction referral distribution of RGB 3 (CIE 1931), (b) distribution of y-direction referenced RGB 3 (CIE 1931)

In Table 1 the following shows a comparison of the value of variants from the three reference colors.

Table 1. Comparison of variance values and RGB mean on the CIE 1931 curve

\begin{tabular}{|l|l|c|l|}
\hline No & Referral Color & Variant Value & Average \\
\hline 1 & CIE 1931 & RGB 1 $=0.000189$ & 0.026042 \\
& & RGB 2 $=0.000160$ & 0.022395 \\
& & RGB 3 $=0.000120$ & 0.024355 \\
\hline
\end{tabular}

The meaning of Table 1 is to find out the comparison of the results of the variance values of each reference color, especially RGB 1, RGB 2 and RGB 3 in CIE 1931. It turns out that the smallest variance of the value is RGB 3, which is purple.

In Table 2 the following shows the comparison of the variance values of the three reference colors. The distribution value of CIE 1931 in RGB 1, RGB 2 and RGB 3 in this study has two distributions, 
namely the $\mathrm{x}$-direction distribution and the $\mathrm{y}$-direction distribution and the average of the three RGBs.

Table 2. $x$-direction distribution values and y-direction distribution values on the CIE 1931 curve

\begin{tabular}{|c|l|l|l|l|l|}
\hline No & $\begin{array}{l}\text { Referral } \\
\text { Color }\end{array}$ & $\begin{array}{l}\text { X-Direction } \\
\text { Variant }\end{array}$ & Average & $\begin{array}{l}\text { Y-Direction } \\
\text { Variant }\end{array}$ & Average \\
\hline 1 & CIE 1931 & RGB 1 $=0.0000001146$ & 0.0003982024 & RGB 1 =0.0000001490 & 0.0004694415 \\
& & RGB 2 $=0.0000004069$ & 0.0006502902 & RGB 2 =0.0000000003 & 0.0000115155 \\
& & RGB 3 $=0.0000000057$ & 0.0000634925 & RGB 3 =0.0000002182 & 0.0006497050 \\
\hline
\end{tabular}

\section{Conclusion}

From the results of research and discussion, the following conclusions are drawn: (1) this system can be used to determine the shift in one's color perception. (2) in the CIE curve of 1931 all the colors contained in the system gamut can give the perception of each color as the color of perception. (3) choosing the color of the reference only takes three colors from the various colors in the system gamut, of the three colors including orange, blue and purple. (4) the spectral color perception detection system model can provide quantitative values in the form of RGB quantities as a result of one's perception, based on the results of the perception of the human eye on color.

\section{Thank-you note}

Thank you to the Faculty of Engineering, Gadjah Mada University, Yogyakarta, especially to the supervisor Prof. Adhi Susanto, M.Sc, Ph.D and Ir. Rudy Hartanto, MT who has provided and taught researchers about image processing in spectral based color detection applications.

\section{References}

[1] Nalwan, A. Seri Aplikasi Pemrograman Pengolahan Gambar Secara Digital. PT Elek Media Komputindo Jakarta 24-28 (1997)

[2] Castleman, K. R. Digital Image Processing, Perceptive Sientific Instrument. Inc Prentice Hall Englewood Cliffs New Jersey 076632. (1996)

[3] Jain, A. K. Fundamental of Digital Image Processing. Prentice Hall International Edition New Jersey USA Inc Singapore 123-130. (1989)

[4] Gonzales, R. C., Wood, R. E. Digital Image Processing. Addison Wesley Publishing Company Inc 178-180. (1993)

[5] Lun, K. NTSC Colours on Workstation Monitors 120-125 (1997) 
[6] Awcock, G. J., Thomas, R. Applied Image Processing and Pattern Recognition. Prentice Hall International (UK) Ltd (1995)

[7] Young, C. C., John, F. R. RGB Calibration for Color Image Analysis in Machine Vision. IEEE Trans Image Processing Vol. 5 No. 10 PP.1414-1422 (1996)

[8] Rao, A. S., Rohini, K., Zhang, Z. Spasial Color Histograms for Content-Based Image Rentival Center of Excellence for Dociment Analysis and Recognition State University New York (1999)

[9] Sharman, G., Member IEEE., H. J Trussell Fellow IEEE. Digital Color Imaging IEEE Trans Image Processing Vol. 6 No. 7 PP 901-925. (1997)

[10] Hill, F. S. Computer Graphics. MacMillan Publishing Company A Division of MacMillan Inc Singapore (1990)

[11] Phillips, D. Image Processing in C, R and D Publications Inc Kansas USA (1994)

[12] Pitas, I. Digital Image Processing Algoritms Prentice Hall International (UK) Ltd (1993) 